\title{
ESM1 Gene
}

National Cancer Institute

\section{Source}

National Cancer Institute. ESM1 Gene. NCI Thesaurus. Code C104087.

This gene may play a role in endothelial cell-leukocyte interactions. 